\title{
CARA UJI STATISTIK MENGGUNAKAN SPSS
}

\author{
Muh Fadli Fajrin, Herianto \\ Sekolah Tinggi Agama Islam (STAI) Darul Da'wah Wal-Irsyad (DDI) Kota Makassar, Indonesia \\ Email : muhfadlifajrin1234@gmail.com \\ Sekolah Tinggi Agama Islam (STAI) Darul Da'wah Wal-Irsyad (DDI) Kota Makassar, Indonesia \\ Email : antoherianto47@gmail.com
}

\begin{abstract}
ABSTRAK
Artikel Uji Validitas dan Uji Reabilitas dengan SPSS ini menggunakan kolerasi product moment. Validitas dan Reliabilitas bertujuan untuk mengetahui sejauh mana kuesiner yang dibuat tepat dan dapat di andalkan untuk sebuah penelitian. Sebelum kita melakukan pengujian baiknya kita ketahui terlebih dahulu apa dan bagaimana suatu kuesioner bisa dikatakan valid dan reliabel.
\end{abstract}

Kata Kunci : Cara Uji Statistik, Menggunakan SPSS 


\section{A. PENDAHULUAN}

Didalam Ilmu belajar Matematika, tidaj hanya mengandalkan sebuah pikiran yang di fokuskan kepada materi tersebut melainkan dapat juga mengandalkan atau memakai Aplikasi yang bernama SPSS, Aplikasi ini sangat berguna bagi si pemakai untuk mengetahui hasil statistic.

\section{B. PEMBAHASAN}

\section{Klasifikasi Statistik}

Statistik dapat dibedakan menjadi dua, yaitu statistik deskriptif dan statistik inferensial.

\section{a. Statistik Deskriptif}

Adalah statistik yang digunakan untuk menggambarkan atau menganalisis suatu statistik hasil penelitian, tetapi tidak digunakan untuk membuat kesimpulan yang lebih luas atau generalisasi.

Penelitian yang tidak menggunakan sampel, analisanya akan menggunakan statistik deskriptif

b. Statistik inferensial adalah statistik yang digunakan untuk menganalisis data sampel, dan hasilnya akan digeneralisasikan untuk populasi dimana sampel diambil.

Statistik inferensial dibagi menjadi dua macam, yaitu statistik parametris dan statistik non parametris. 
$\varnothing$ Statistik parametris

Digunakan untuk menganalisis data interval atau rasio yang diambil dari populasi yang berdistribusi normal, jumlah sampel harus sama atau lebih dari 30. Untuk uji hubungan yang bersifat pengaruh fungsiolnal dan menggunakan variable independen lebih dari satu maka harus memenuhi asumsi klasik statistik.

Metode statistik yang sering digunakan pada statistik parametric, antara lain : uji beda dua sampel berpasangan t-paired, correlation pearson, regresi linear, analisis diskriminan dan analisis faktor

$\varnothing$ statistik non parametris

Digunakan untuk menganalisis data nominal dan ordinal dari populasi yang bebas berdistribusi dan jumlah sampel kurang dari 30. Metode statistik yang sering digunakan antara lain : binomial non parametric test, run test, chi square test, wilcoxon, kolmogorov-smirnov, mann whitney test da Cochran test.

\section{Klasifikasi data statistik}

Data hasil penelitian dapat dikelompokkan menjadi dua, yaitu data kualitatif dan data kuantitatif.

\section{a. Data kualitatif}

Adalah data yang berbentuk kalimat, kata atau gambar. 


\section{b. Data kuantitatif}

Adalah data yang berbentuk angka, atau data kualitatif yang diangkakan (scoring). Data kuantitatif dapat dikelompokkan menjadi dua, yaitu data diskrit dan data kontinum.

Data diskrit adalah data yang diperoleh dari hasil menghitung atau membilang (bukan mengukur). Data ini sering disebut juga dengan data nominal. Data nominal biasanya diperoleh dari penelitian yang bersifat eksploratif atau survey.

Data kontinum adalah data yang diperoleh dari hasil pengukuran. Data kontinum dikelompokkan menjadi tiga macam, yaitu data ordinal, interval dan rasio

$\varnothing$ Data ordinal

adalah data yang berjenjang atau berbentuk peringkat, misalnya juara I, II; golongan I,II,III dst. Data ordinal ini dapat dibentuk dari data interval atau rasio.

\section{$\varnothing$ Data Interval}

adalah data yang jaraknya sama, tetapi tidak mempunyai nilai nol absolute (mutlak). Data interval dalam penelitian social biasanya instrument (kuesioner) menggunakan skla likert, Guttman, Semantic Differential, Thurstone. Data interval dapat dibuat menjadi data ordinal 


\section{$\varnothing$ Data Rasio}

adalah data yang jaraknya sama dan mempunyai nilai nol absolute. Data ini bias dibuat penjumlahan atau perkalian, data rasio adalah data yang paling teliti. Data ini dapat disusun kedalam data interval atau ordinal.

3. Klsifikasi metode statistik berdasarkan jumlah variabel penelitian

Dilihat dari jumlah variabel penelitian yang digunakan, metode statistik dikelompokkan menjadi tiga, yaitu : statistik univariate, statistik bivariate, dan statistik multivariate.

$\varnothing$ Analsisis univariate

Merupakan metode statistik dalam penelitian yang hanya menggunakan satu variabel. Salah satu bentuk dari analisis univariat ini adalah analisis deskriptif. Beberapa tujuan penelitian yang menggunakan analisis univariat antara lain :

- Mengidentifaksi jumlah katagori, sehingga metode statistik yang digunakan adalah chi square test

- Membedakan proporsi katagori sehingga metode statistik yang digunakan adalah t-test proporsi

- Membedakan urutan katagori, sehingga metode statistik yang digunakan adalah kolmogorov-smirnov test 
- Membedakan nilai sampel dengan populasi, sehingga metode statistik yang digunakan adalah z-test (sampel besar) atau t-test (sampel kecil)

\section{$\varnothing$ Analisis Bivariate}

Analisis bivariat pada umunya mempunyai tujuan untuk menguji perbedaan dan menguji hubungan antara dua variabel penelitian yang digunakan. Untuk pengujian perbedaan antara dua kelompok independen, metode statistik yang sering digunakan adalah Z-test dan chi-square test.

Uji hubungan pada analisis bivariate lebih sering berbentuk hubungan yang bersifat korelasional.

$\varnothing$ Analisis Multivariate

Analisis multivariate dikelompokkan mejadi dua bentuk, yaitu

- $\quad$ Analisis dependensi, digunakan untuk menjelaskan dan memprediksi satu atau lebih variabel dependen yang didasarkan pada variabel-variabel independen yang digunakan. Metode yang sering digunakan : analisis diskriminan, analisis regresi linear berganda, Manova

- $\quad$ Anlisis interpendensi, digunakan untuk mengetahui struktur dari sekelompok obyek, dimensi, atau variabel. Metode statisitk yang sering digunakan adalah analisis factor dan cluster analysis. 
Memasukkan dan mengolah data ke spss :

Menu utama program SPSS ini ditunjukan pada lingkaran seperti yang tampak dibawah ini

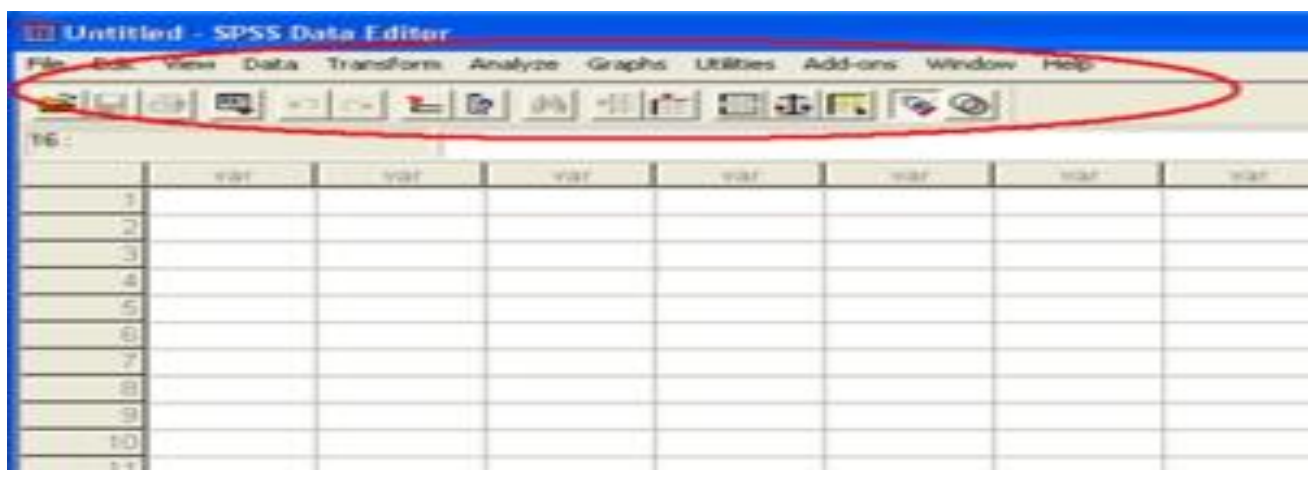

Tampilan layar SPSS ada 2 yaitu Data view dan variabel view yang dtunjukan dibawah ini

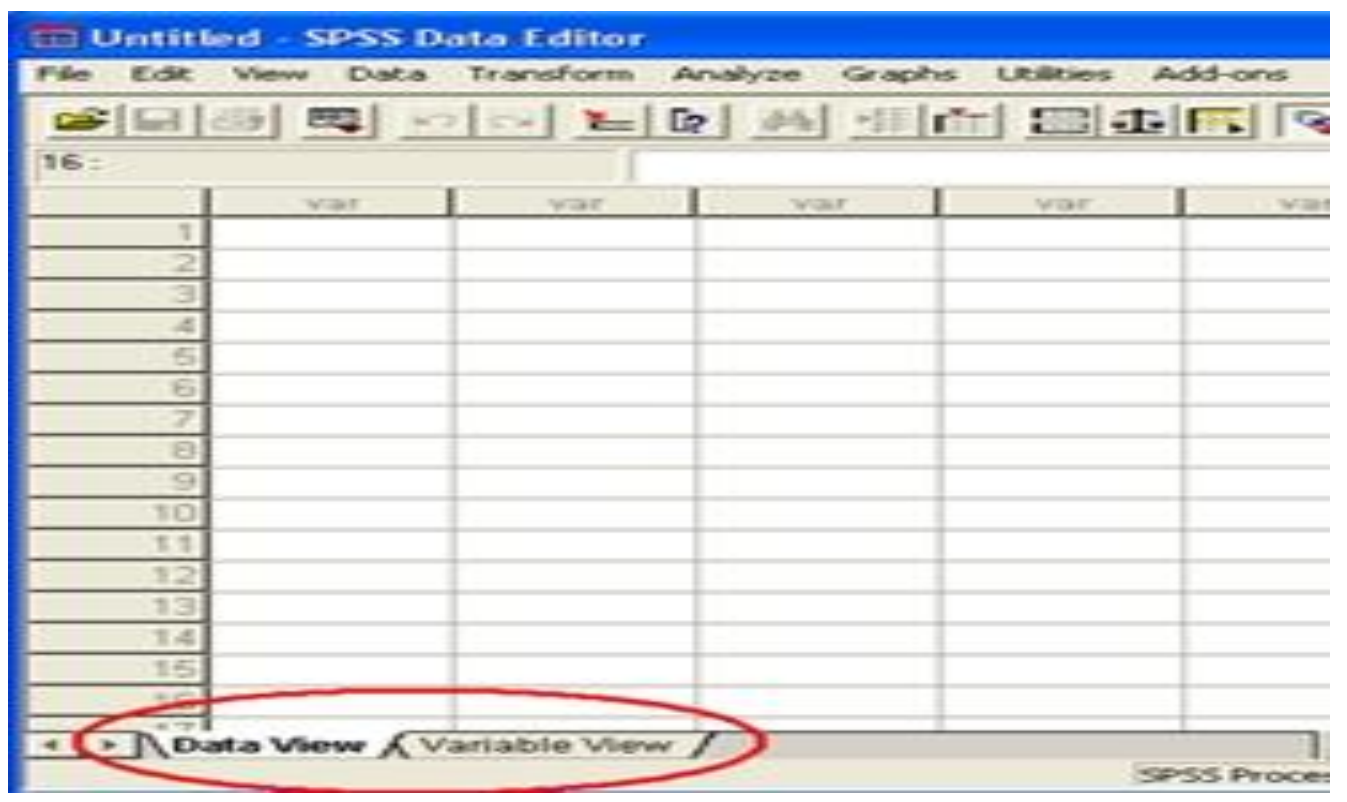


Data view adalah data yang tampilannya seperti exel, data view ini sebagai lembar kerja.

Untuk melihat tampilan data view,dengan meng-klik tulisan (data view)

Dan tampilannya sebagaiberikut :

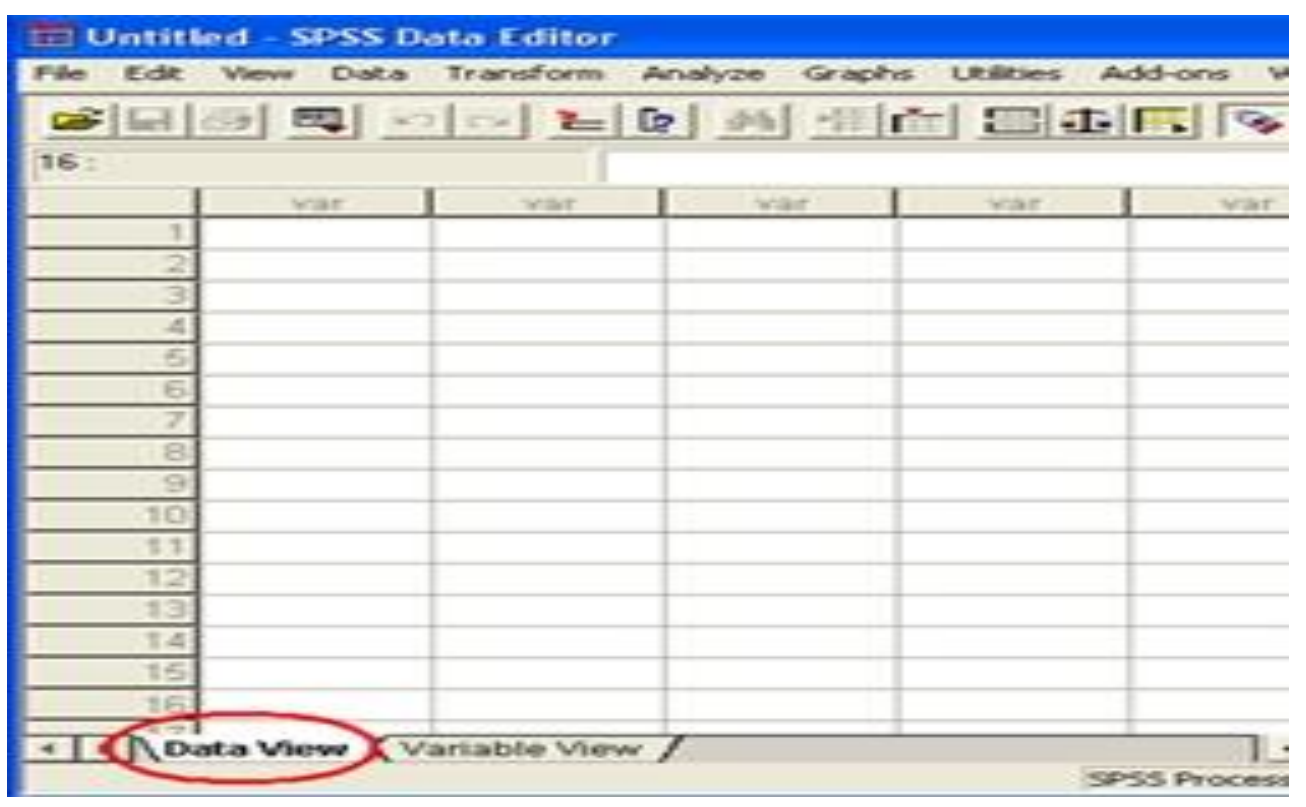

Sedangkan variable view berperan sebagai definisi operasional yang hasilnya nanti akan terlihat di data view. Untuk melihat tampilan variable view, dengan meng-klik (variable view) sepeti di tunjukan lingkaran merah,dan tampilan variable view seperti dbawah ini 


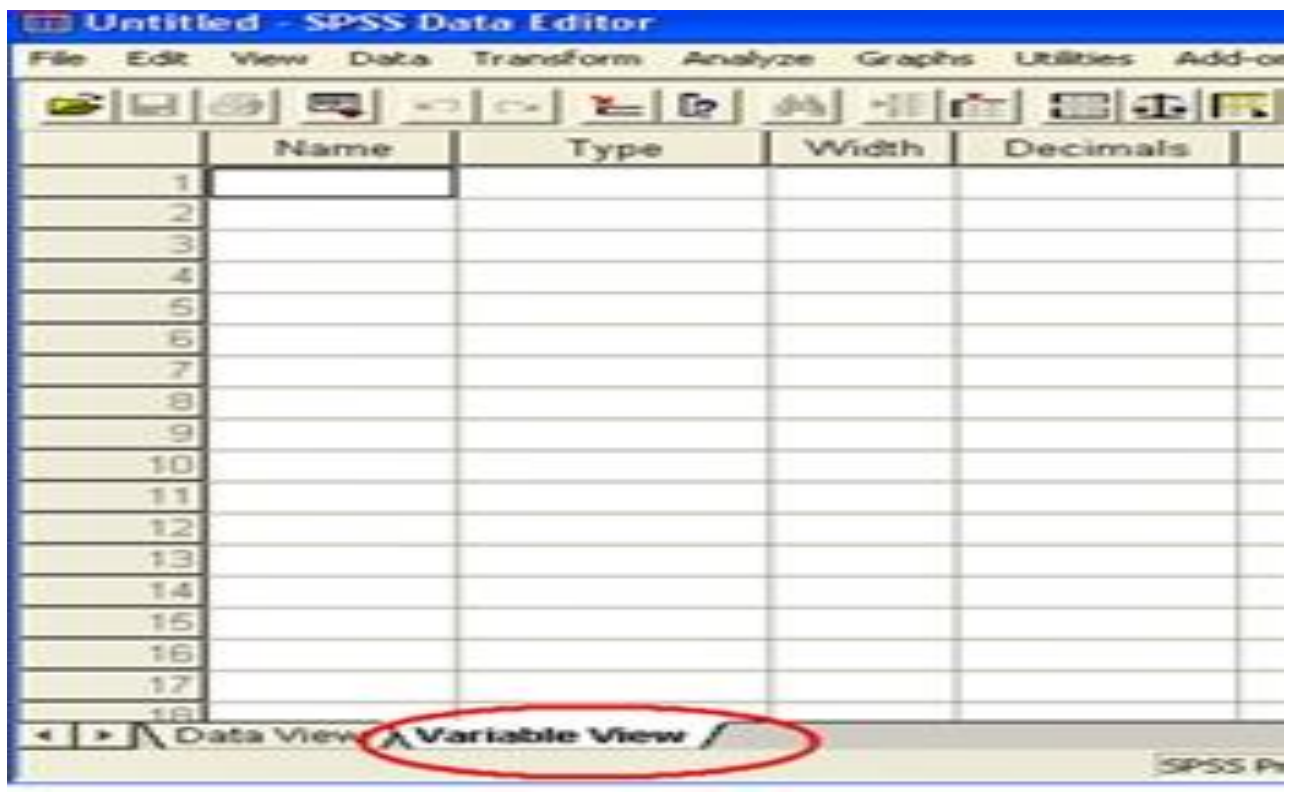

Inilah pengenalan Program SPSS secara garis besar.

Untuk mengenal SPSS lebih jauh, mari kita mencoba mengolah data menggunakan analisis regresi dengan menggunakan SPSS 12.0

Hal pertama yang kita lakukan adalah memasukan data pada halaman DATA VIEW di SPSS,kemudian ketik nilai variabel-variabel (Y,X1, dan X2) 


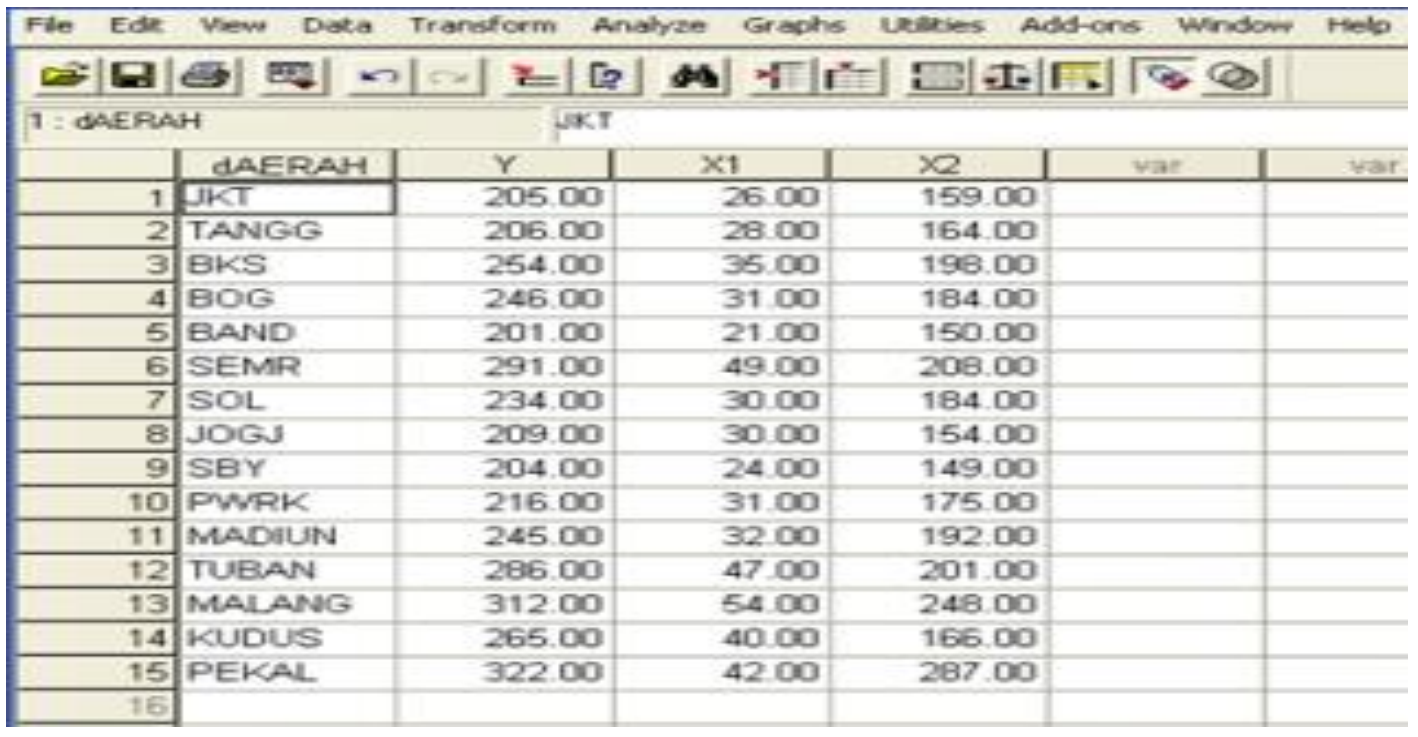

Pada halaman VARIABEL VIEV, dalam kolom Name ketik simbol (Y,X1,X2 ) dan pada Kolom Label ketikan nama Variabel ( Daerah,Sales,Promo dan Outlet)

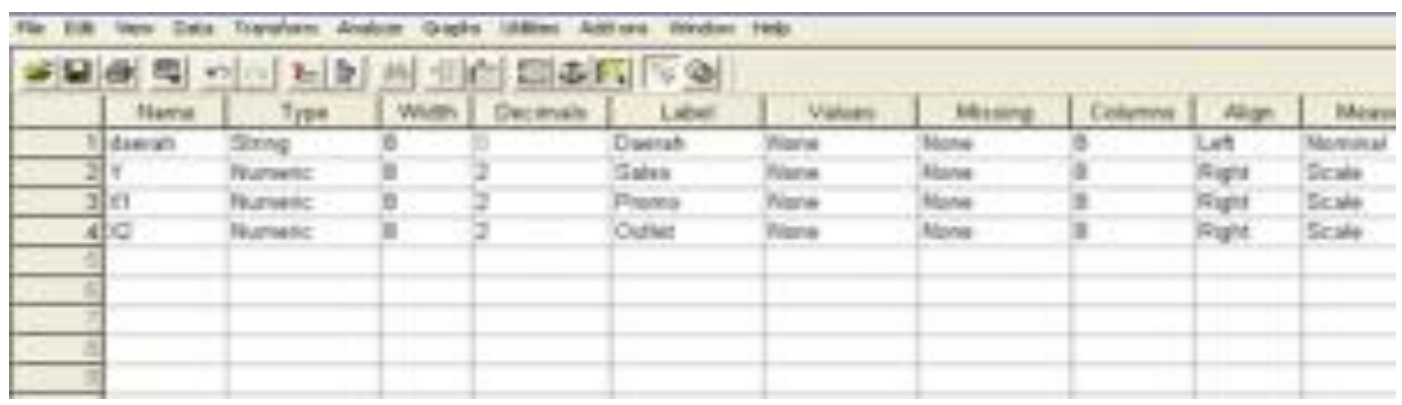

Pada kolom Type, variabel Y di pilih tipe Srting karena data yang ditampilkan pada DATA VIEW berupa huruf (nama daerah) sedangkan pada variabel X1,X2,X3 dipilih type Numeric karena data yang dtampilkan berupa angka. 


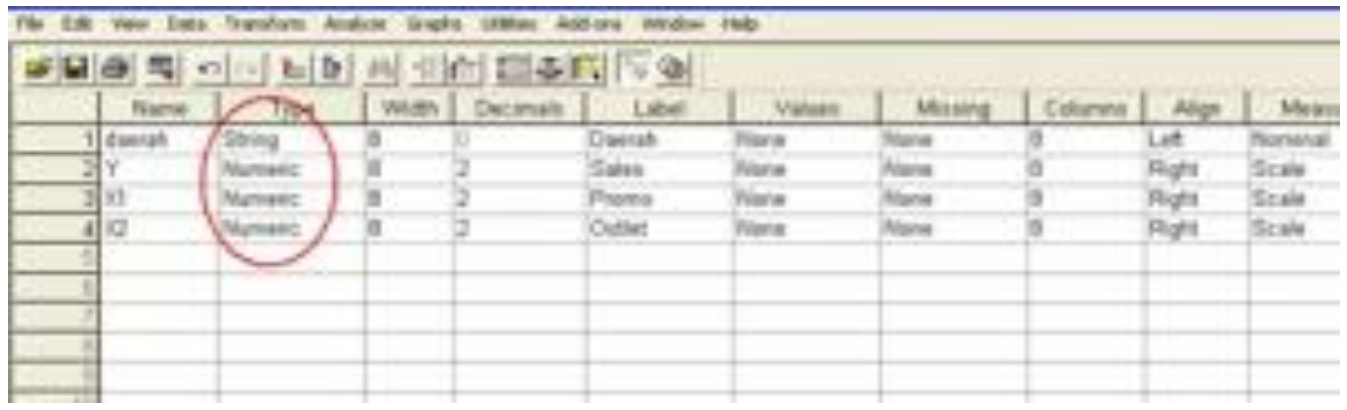

Selanjutnya untuk mengolah data menggunakan analisis regresi, lakukan langkahlangkah berikut.

Klik Analyze, Regression, Linear

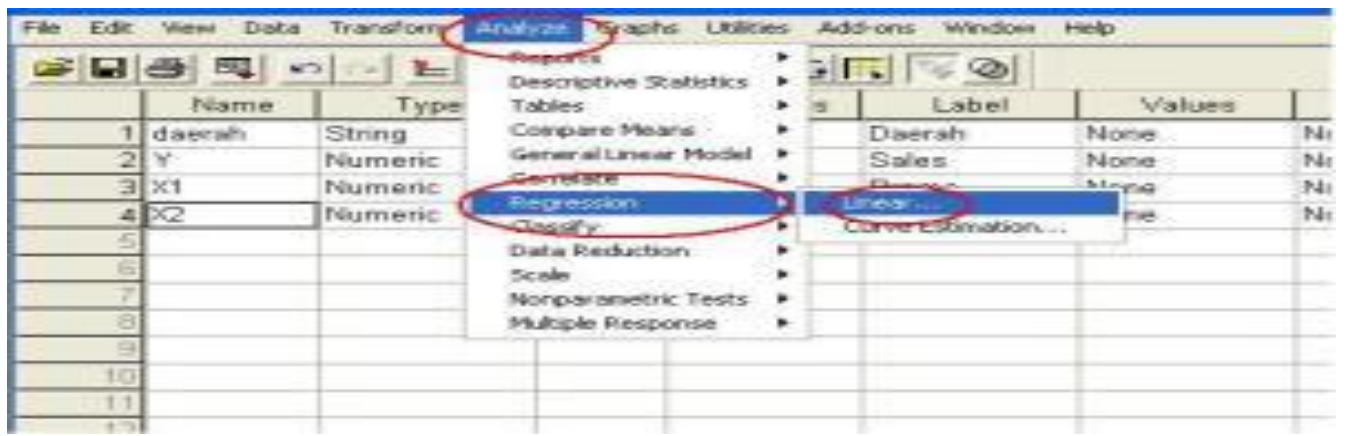

Sehingga tampak tampilan seperti dibawah ini. 


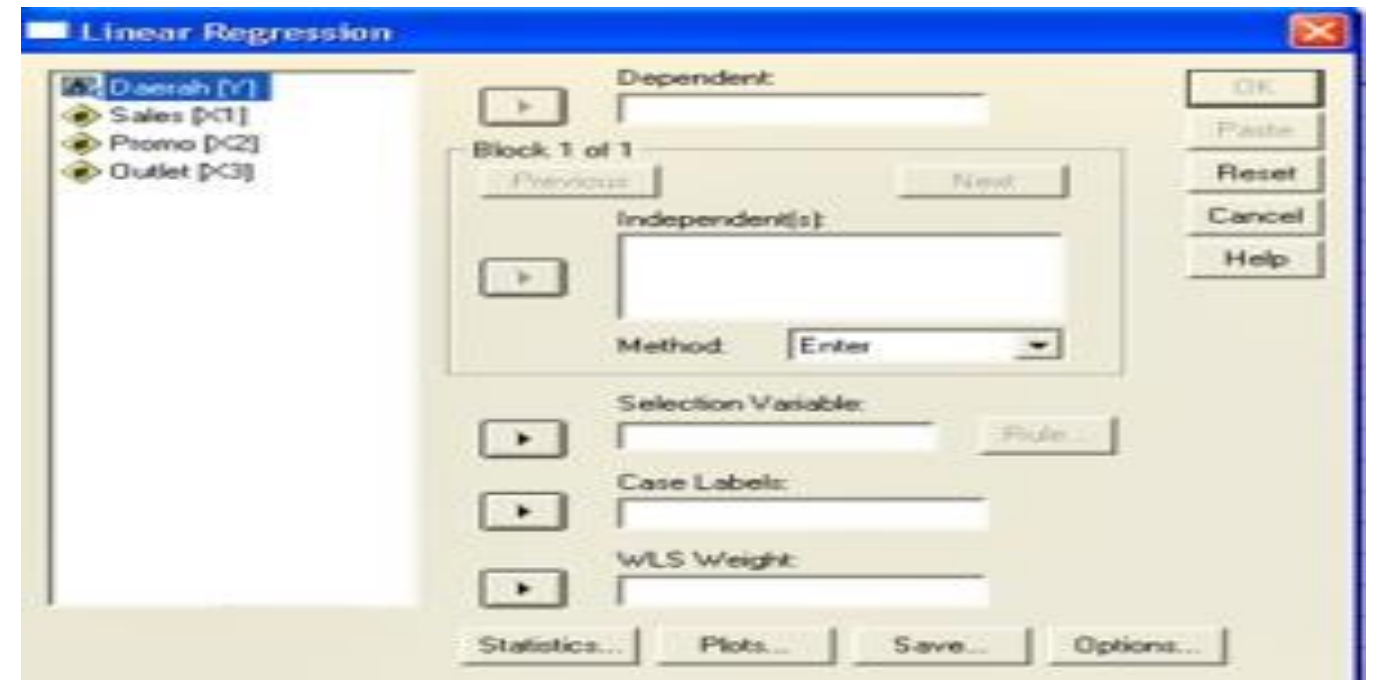

Kemudian pindahkan Promo(x1),Outlet(x2) ke dalam kotak independent(s) dan Sales

(y) pada kotak dependen seperti dibawah ini.

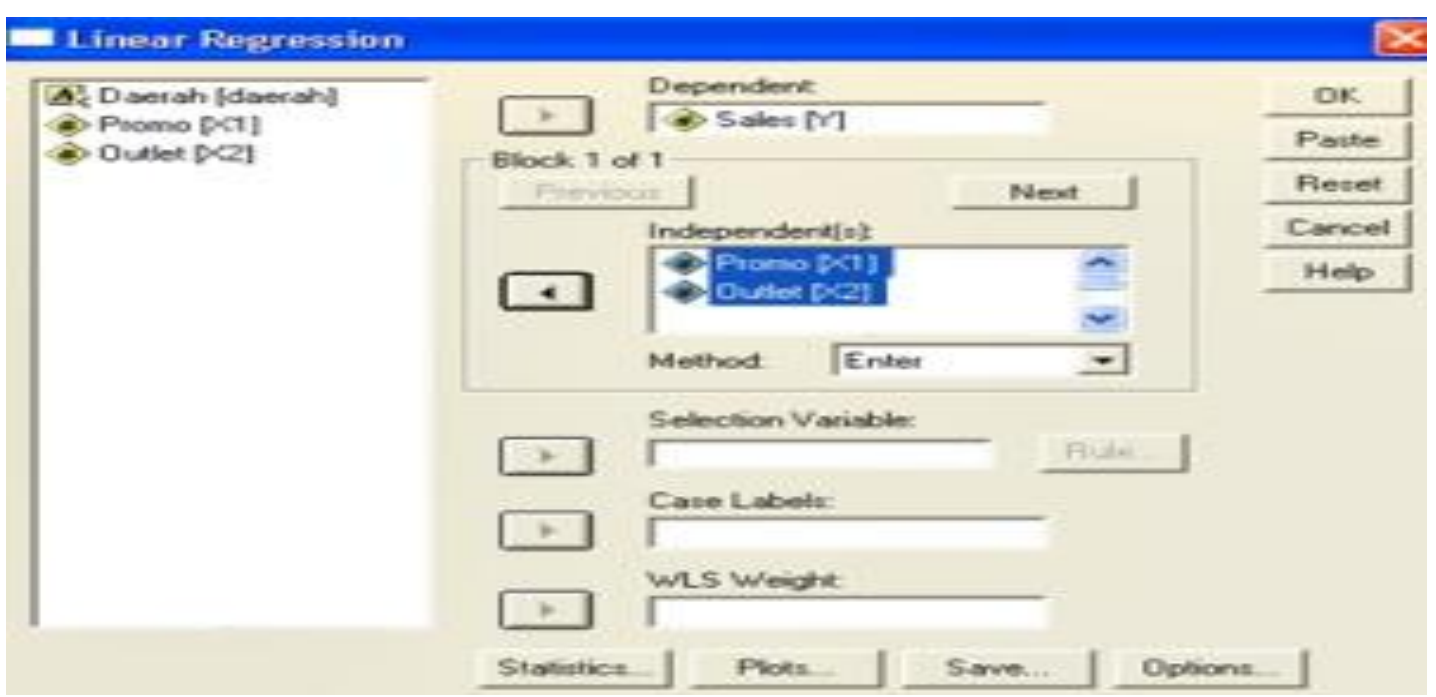

Kemudian klik"statistics" sperti yang ditunjukan dibawah ini. 


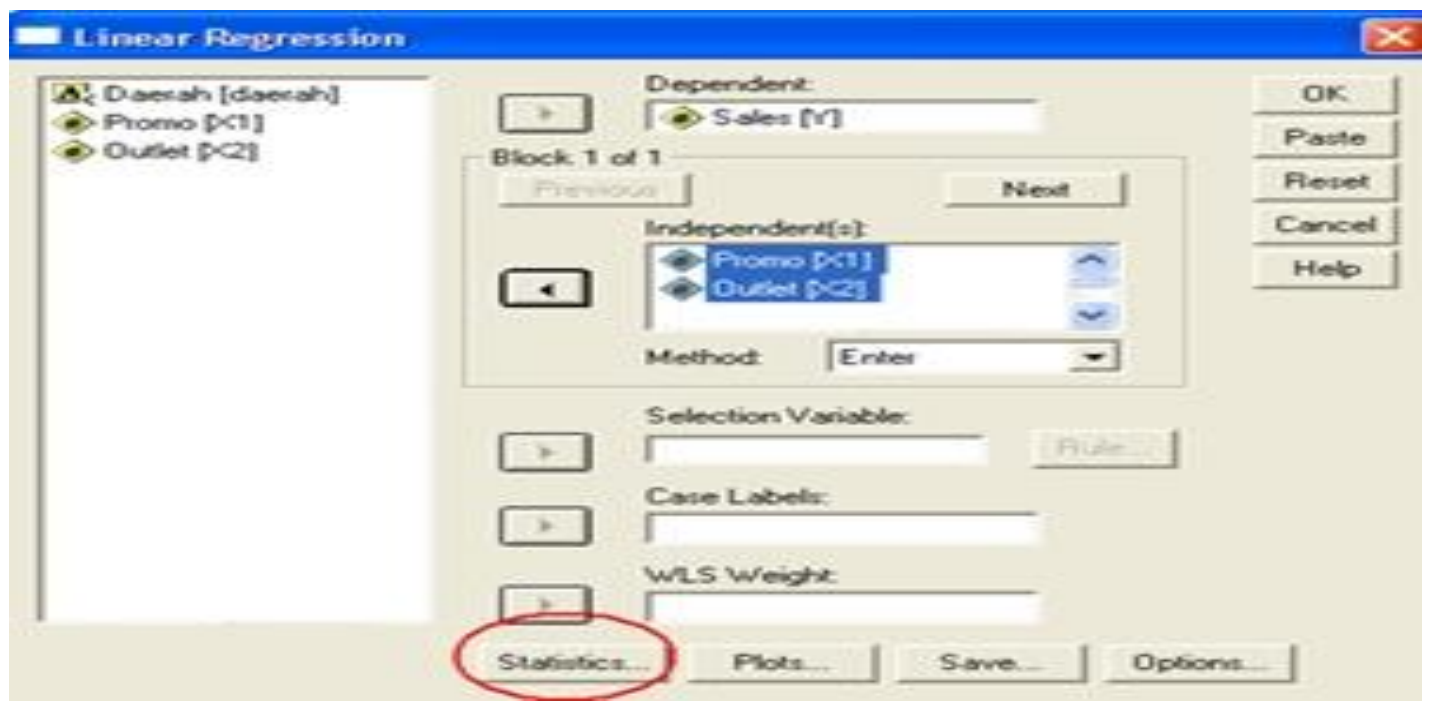

Selanjutnya akan tampak tampilan sperti dibawah ini, kemudian beri centang pada

Estimates, Model fit, R Squared change,Descriptives,part and partial

correlations,collinerity diagnostics

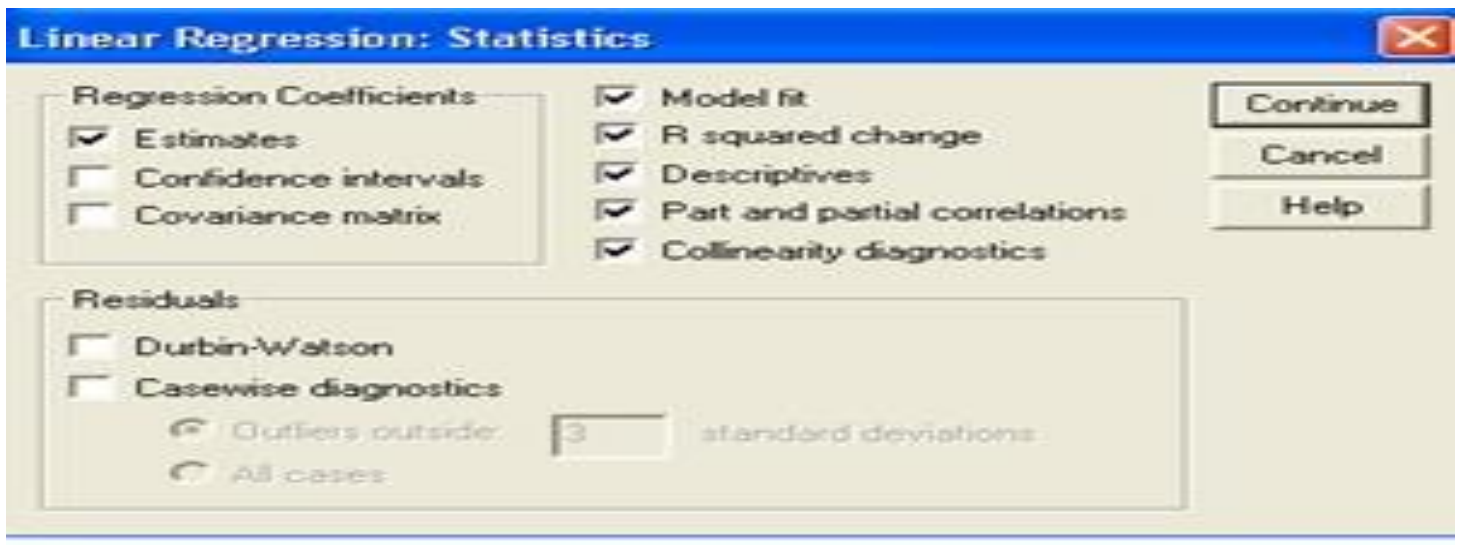

klik continue.. 


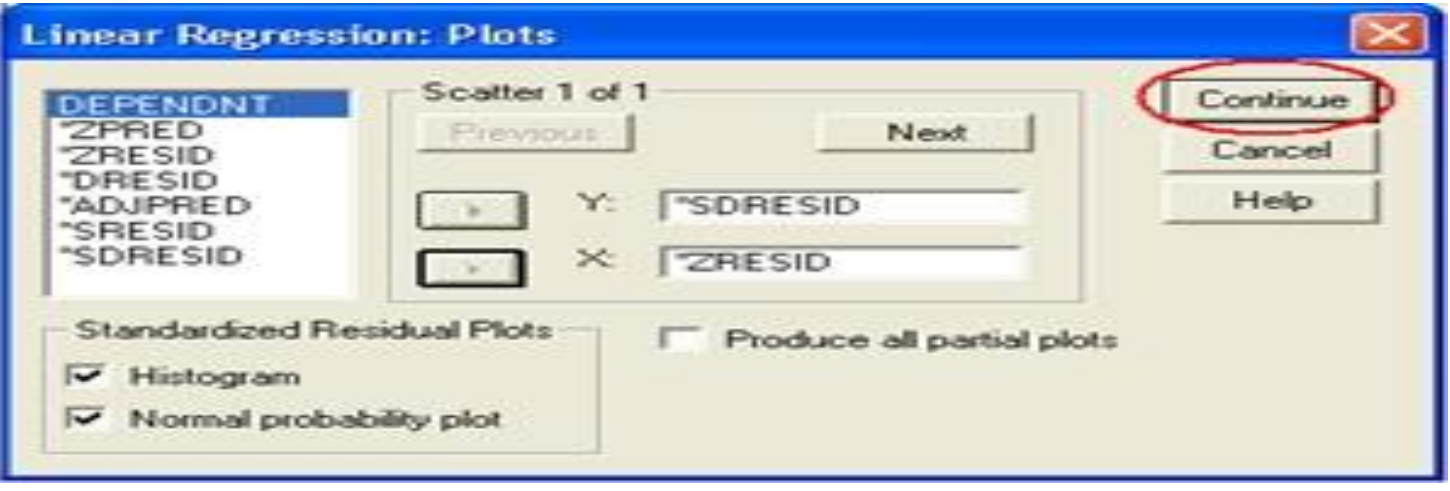

Selanjutnya akan tampil menu semula kemudian klik plot..

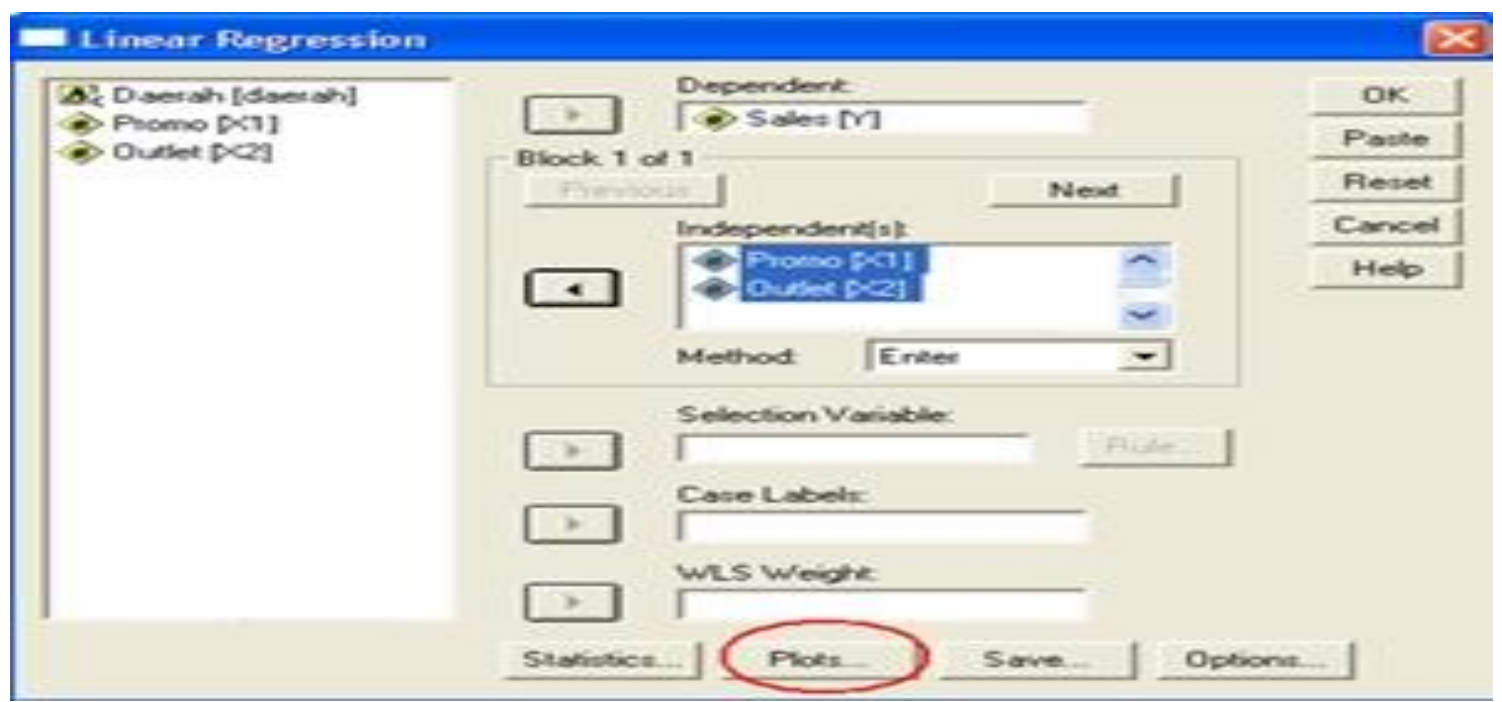

Kemudian tampilan plot sebagai berikut,

Dan masukan *SDRESID pada Y dan *ZRESID pada X seperti dibawah ini,kemudian klik"continu sehinnga tampilannya menjadi sebagai berikut : 


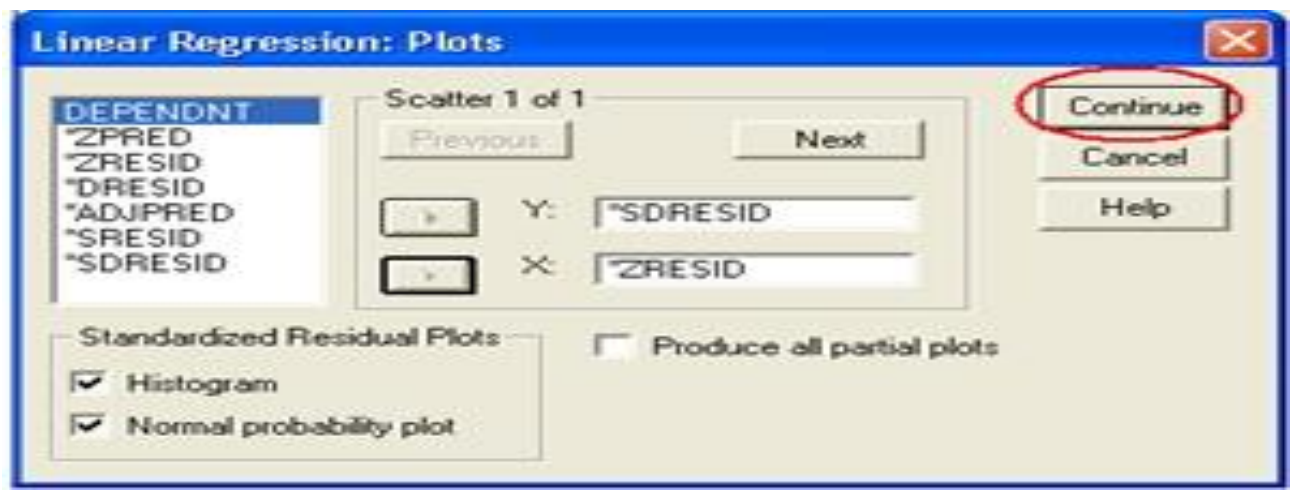

kemudian akan tampak tampilan semula lalu Klik "ok"

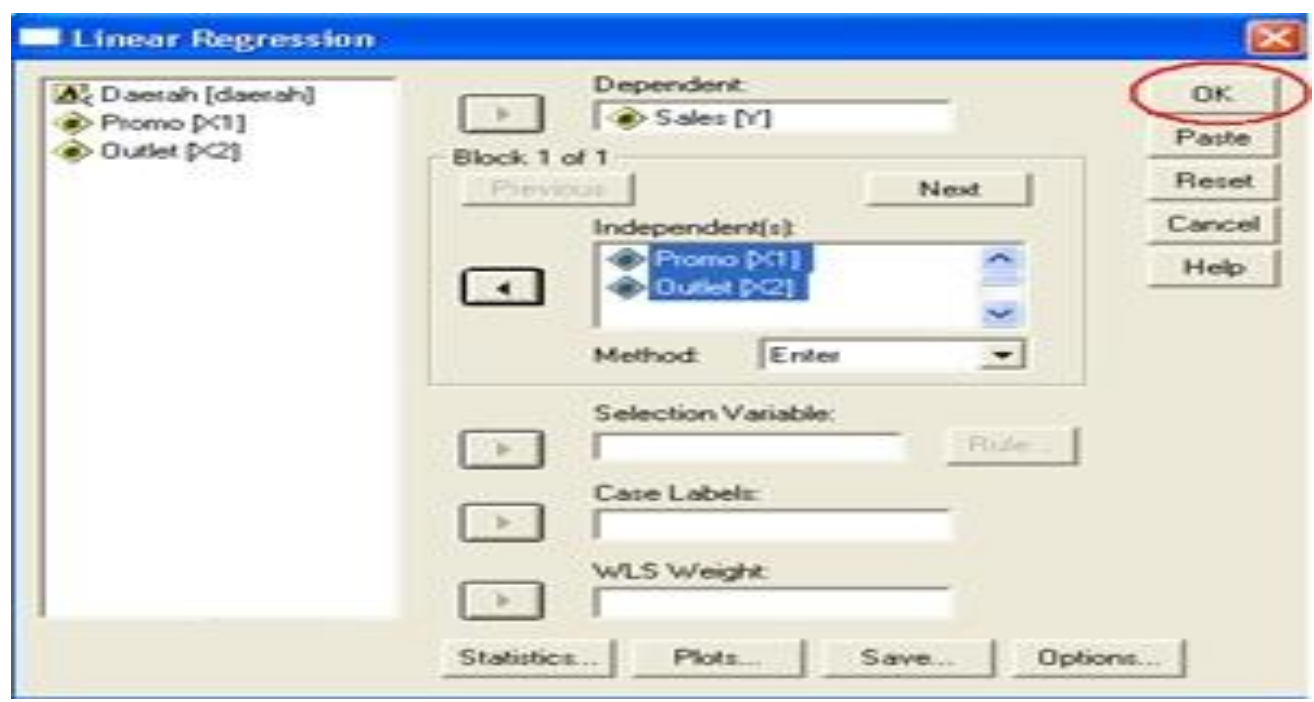

Sehingga secara otomatis lembar output dari pengolahan data menggunakan analisis regresi dengan spss 12.0 ini ditampilkan seperti dibawah ini.. 

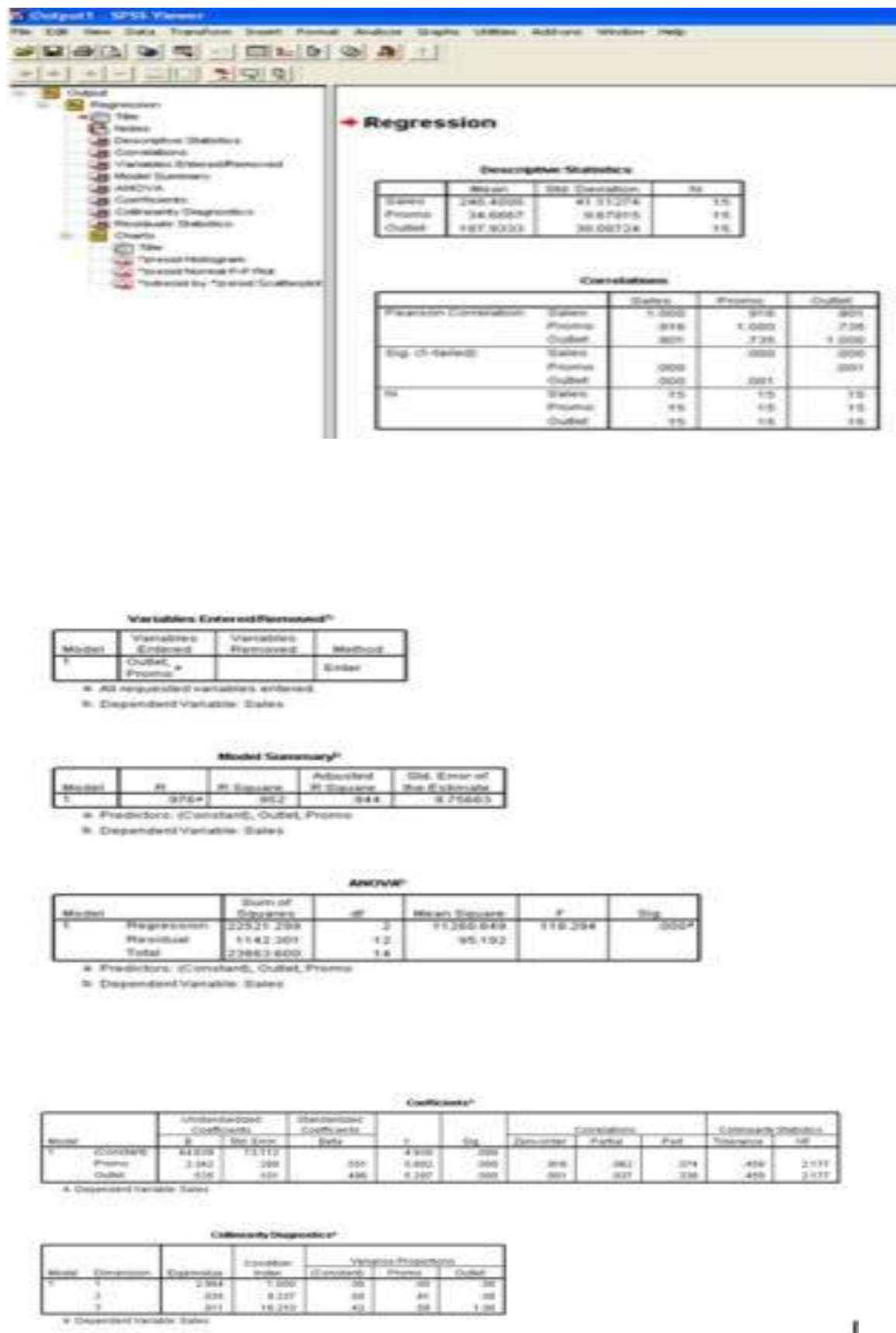
Poesiduals Statistics?

\begin{tabular}{|c|c|c|c|c|c|}
\hline & Mnimam & Heamum & Mean & Sta. Deviat on & $N$ \\
\hline Presctes value & $194.02+1$ & 323.8252 & 2464000 & 40.10818 & 15 \\
\hline std. Predicted Value & -1.304 & 1930 & 000 & 1.000 & 15 \\
\hline $\begin{array}{l}\text { Standand Emer of } \\
\text { Presictes Value }\end{array}$ & 2.683 & 8.491 & 4.093 & 1,566 & 15 \\
\hline Adiusted Predicsed Valog & 192.2514 & 330.2918 & 2453033 & 39.12400 & 15 \\
\hline Residual & -1489111 & 17,84460 & 00000 & 9.03288 & 15 \\
\hline Sto. Residual & -1.526 & 1828 & 000 & 926 & 15 \\
\hline Stud. Residual & -1.599 & 2.095 & 027 & 5.058 & 15 \\
\hline Deleted Residus: & -18.29182 & 23,41938 & 109674 & 1249982 & 15 \\
\hline Stud. Deleted Residual & -1.712 & 2519 & 047 & 1. 145 & 15 \\
\hline Wahe Oisante &, 126 & 9669 & 1.857 & 2.461 & 15 \\
\hline Cook's Distante & .000 & 1319 & 157 & 350 & 16 \\
\hline Cendered Leverage Valoo & 009 & 691 & 13 & 178 & 15 \\
\hline
\end{tabular}

a. Dependent Variable: Sales
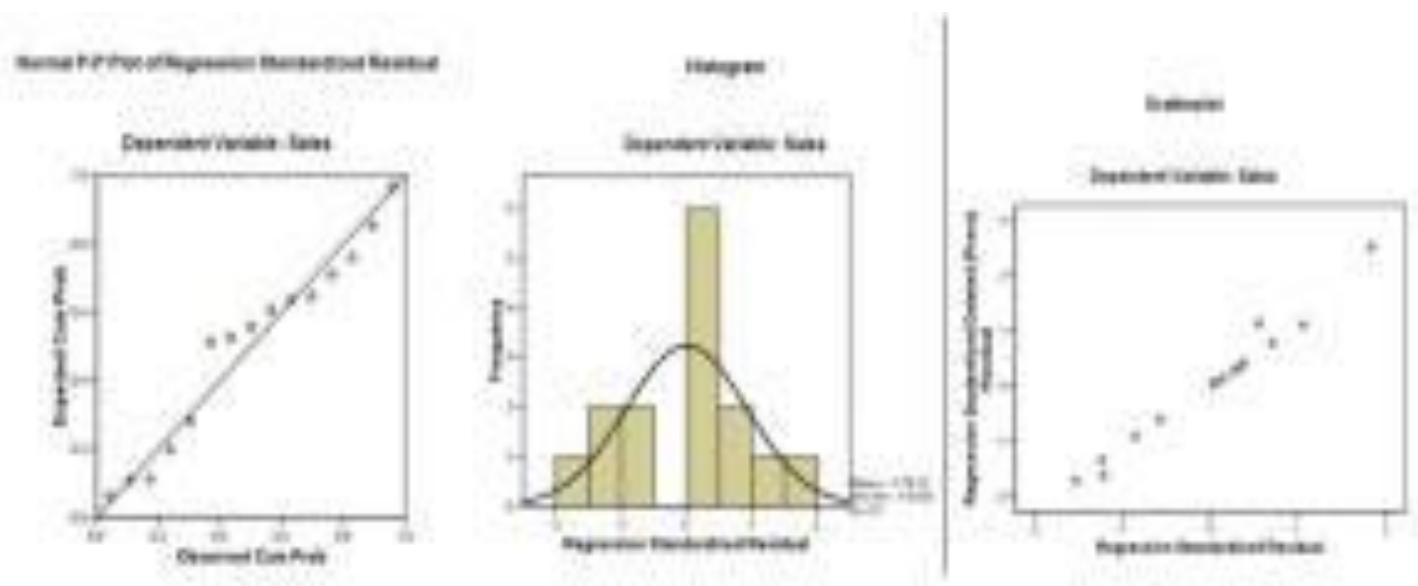

Demikianlah salah satu cara memasukkan dan mengolah data menggunakan SPSS

. Untuk anda ketahui ,disini saya menggunakan SPSS 12 . 


\section{PENUTUP}

\section{KESIMPULAN}

Dimana kita ketahui sebelumnya, bahwa SPSS adalah aplikasi komputasi untuk perhitungan statistik, merupakan piranti lunak komputer yang saat ini lisensinya dimiliki oleh IBM. SPSS ini merupakan salah satu sofware statistik yang paling populer di dunia, terutama juga di Indonesia. Namun sayangnya, tutorial SPSS berbahasa Indonesia sangatlah minim. 


\section{DAFTAR PUSTAKA}

[15:47, 1/18/2021] Dosenku Heriyanto: Jusmiana, A., Herianto, H., \& Awalia, R. (2020). Pengaruh Penggunaan Media Audio Visual Terhadap Hasil Belajar Matematika Siswa Smp Di Era Pandemi Covid-19. Pedagogy: Jurnal Pendidikan Matematika, 5(2), 1-11.

[15:48, 1/18/2021] Dosenku Heriyanto: Herianto, H., \& Hamid, N. (2020). Analisis Proses Berpikir Kreatif Dalam pemecahan Masalah Geometri Berdasarkan Gaya Kognitif Reflektif Dan Impulsif Siswa. Pedagogy: Jurnal Pendidikan Matematika, $5(2), 38-49$.

[15:48, 1/18/2021] Dosenku Heriyanto: Munir, M. B., \& Herianto, H. (2020). Tingkat Pemahaman Moderasi Beragama Serta Korelasinya Terhadap Pengaruh Kesehatan Mental, Keaktifan Berorganisasi dan Prestasi Akademik. Prosiding Nasional, 3, 137150. 